\title{
Rural area of the Brazilian Pantanal wetlands associated with the occurrence of anti-Leishmania spp. antibodies in dogs
}

\author{
Área rural do Pantanal brasileiro associada à ocorrência \\ de anticorpos anti-Leishmania spp. em cães
}

\author{
Andréia Lima Tomé MELO ${ }^{1}$; Andréa Pereira da COSTA²; Selma Samiko MIYAZAKI³; Matias Bassinello STOCCO ${ }^{4}$; \\ Thiago Borges Fernandes SEMEDO ${ }^{5}$; Thábata dos Anjos PACHECO 4 ; Rute WITTER ${ }^{4}$; \\ Richard de Campos PACHECO ${ }^{4}$; Marcelo Bahia LABRUNA²; Arlei MARCILI²,; Daniel Moura de AGUIAR ${ }^{4}$ \\ ${ }^{1}$ Universidade de Cuiabá, Curso de Medicina Veterinária, Cuiabá - MT, Brazil \\ ${ }^{2}$ Universidade de São Paulo, Faculdade de Medicina Veterinária e Zootecnia, São Paulo - SP, Brazil \\ ${ }^{3}$ Instituto Chico Mendes de Conservação da Biodiversidade, Estação Ecológica de Taiamã, Cáceres - MT, Brazil \\ ${ }^{4}$ Universidade Federal de Mato Grosso, Faculdade de Medicina Veterinária, Cuiabá - MT, Brazil \\ ${ }^{5}$ Universidade Federal de Mato Grosso, Instituto de Biociências, Cuiabá - MT, Brazil \\ ${ }^{6}$ Universidade de Santo Amaro, Mestrado em Medicina Veterinária e Bem-Estar Animal, São Paulo - SP, Brazil
}

\begin{abstract}
An evaluation was made of the presence of anti-Leishmania infantum chagasi antibodies in domestic dogs from the urban and rural areas of Brazil's Pantanal wetland region using serological techniques. A total of 429 dogs were sampled in three areas of the Pantanal biome, including the municipalities of Poconé, Santo Antônio de Leverger, and Barão de Melgaço, in the state of Mato Grosso, and in the municipality of Corumbá, in the state of Mato Grosso do Sul. The immunofluorescence assay (IFA) was used to detect antibodies (cut-off point 40) using Leishmania infantum chagasi antigen. Because of the possibility of cross-reactivity between species of the genus Leishmania, samples that were positive in the IFA against L. infantum chagasi were also tested by IFA in the same conditions, using L. amazonensis and L. braziliensis antigens. IFA-positive samples to L. infantum chagasi were also evaluated using Enzyme-Linked Immunosorbent Assay (ELISA). The results showed the presence of antibodies against L. infantum chagasi in 23 (5.36\%; 95\% CI: 3.50\%-8.05\%) dogs and at least one seroreactive dog was found in each of the municipalities evaluated in this study. Antibody titers ranged from 40 to 5,120, and all IFA positive samples were positive in the ELISA. Among the 23 positive dogs, nine were also were seroreactive for L. amazonensis and L. braziliensis antigens. The occurrence of anti- $L$. infantum chagasi antibodies in dogs was higher in rural areas $(7.06 \%)$ than in urban areas $(2.50 \%)(\mathrm{P}<0.05)$. Based on this study, we concluded that dogs from rural areas of the Pantanal wetlands were in contact with Leishmania species, which is relevant information given their importance to public health.
\end{abstract}

Keywords: Dog. Leishmania spp. Antibodies. IFA. ELISA. Pantanal.

\section{Resumo}

Neste trabalho foi realizada uma avaliação sobre a presença de anticorpos anti-Leishmania infantum chagasi em cães domésticos das áreas urbanas e rurais da região do Pantanal brasileiro usando técnicas sorológicas. Um total de 429 cães foram amostrados em três áreas do bioma do Pantanal, incluindo os municípios de Poconé, Santo Antônio de Leverger e Barão de Melgaço, em Mato Grosso, e o município de Corumbá, em Mato Grosso do Sul. A reação de imunofluorescência indireta (RIFI) foi utilizada para detectar anticorpos (ponto de corte de 40) de Leishmania infantum chagasi como antígeno. Devido à possibilidade de reação cruzada entre as espécies do gênero Leishmania, as amostras positivas na RIFI para L. infantum chagasi foram também avaliadas na RIFI utilizando L. amazonensis e L. braziliensis como antígenos. As amostras positivas na RIFI para L. infantum chagasi foram avaliadas utilizando o ensaio de imunoadsorção ligado à enzima (ELISA). Os resultados mostraram a presença de anticorpos contra L. infantum chagasi em 23 (5,36\%; IC 95\%: 3,50\% -8,05\%) cães e pelo menos um cão soro-reativo foi encontrado em todos os municípios avaliados neste estudo. Os títulos de anticorpos variaram de 40 a 5.120 e todas as amostras positivas na RIFI foram positivas no ELISA. Entre os 23 cães positivos, nove também reagiram para L. amazonensis e L. braziliensis. A ocorrência de anticorpos anti-L. infantum chagasi em cães foi maior nas áreas rurais (7,06\%) do que nas áreas urbanas $(2,50 \%)(\mathrm{P}<0,05)$. Com base neste estudo, concluímos que cães de áreas rurais do Pantanal tiveram contato com espécies de Leishmania, o que é uma informação relevante, dada a sua importância para a saúde pública. Palavras-chave: Cão. Leishmania spp. Anticorpos. RIFI. ELISA. Pantanal. 
Correspondence to:

Andréia Lima Tomé Melo

Universidade de Cuiabá, Curso de Medicina Veterinária

Av. Manoel José de Arruda, 3100 - Jardim Europa

CEP 78065-900, Cuiabá, MT, Brazil

e-mail: andreialtm@gmail.com

Received: 20/03/2017

Approved: 07/08/2017

\section{Introduction}

Leishmaniasis is a zoonotic disease caused by an obligate intramacrophage protozoan of the genus Leishmania (BAÑULS et al., 2007; DAWIT et al., 2013). This parasite is of medical and veterinary public health importance because it infects numerous mammal species, including humans, and is transmitted by the bite of female phlebotomine sand flies of the genus Phlebotomus in the old world and Lutzomyia in the new world. The leishmaniases may have different clinical manifestations such as American visceral leishmaniasis (AVL) and American cutaneous leishmaniasis (ACL) (ASHFORD, 2000; CHAPPUIS et al., 2007; HEUSSER JÚNIOR et al., 2010; BRASIL, 2016). In Brazil the cutaneous form of the disease is usually caused by Leishmania braziliensis and Leishmania amazonensis (BRASIL, 2016).

Leishmania infantum chagasi is the etiological agent of AVL, a chronic disease of which infected dogs are considered reservoirs able to transmit the agent to the vector (LAINSON; RANGEL, 2005; ROQUE; JANSEN, 2014). The principal vectors are Lutzomyia longipalpis and Lutzomyia cruzi, and the latter is implicated in the transmission of AVL in Corumbá and Ladário, two cities situated in the Pantanal wetland biome in the state of Mato Grosso do Sul (SANTOS et al., 1998; LAINSON; RANGEL, 2005; BRASIL, 2016).

The genus Lutzomyia reproduces in solid decomposing organic matter, and the lack of environmental sanitation for the elimination of this matter is associated with the presence of the vector. Therefore, the presence of agriculture and the proximity of dogs to forests, wastelands, and locations that have undergone recent environmental changes also contribute to the vector's development. The urbanization of AVL results from anthropogenic environmental alterations and the rapid and intense migration of rural populations to urban peripheries lacking proper infrastructure, including the concurrent interaction of sylvatic reservoirs and domestic dogs (DIAS et al., 2003; SARAIVA et al., 2017).
The occurrence of L. longipalpis and L. cruzi has been observed in wetland areas. Both species have been reported in the municipality of Poconé, state of Mato Grosso, while only L. cruzi has been described in Santo Antônio de Leverger and Barão de Melgaço, two other municipalities located in the Pantanal wetlands in the state of Mato Grosso (MISSAWA; LIMA, 2006).

Considering the significance of the Pantanal biome as an important region of livestock production activities, fishing and safari tourism, and the presence of dogs in close contact with humans, which are also relevant in the epidemiology of leishmaniasis, the purpose of this study was to determine the occurrence of anti- $L$. infantum chagasi antibodies in domestic dogs from the urban and rural areas of the Pantanal wetlands in the Brazilian states of Mato Grosso and Mato Grosso do Sul.

\section{Materials and Methods}

This study evaluated dogs $(n=429)$ from urban $(\mathrm{n}=160)$ and rural $(\mathrm{n}=269)$ areas sampled from 2009 to 2012 in four municipalities located in the Pantanal wetlands, namely, i) Poconé (56 $\left.37^{\circ} 22^{\prime \prime} \mathrm{W} ; 1^{\circ} 15^{\prime 2} 24^{\prime \prime S}\right)$; ii) Santo Antônio de Leverger (56 $04^{\prime} 47^{\prime \prime} \mathrm{W}$; $15^{\circ} 51^{\prime} 47^{\prime \prime} \mathrm{S}$ );

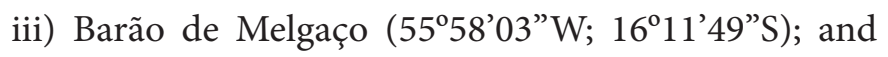

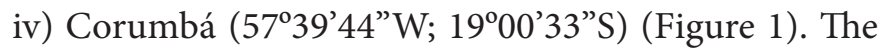
samples from the Poconé municipality were obtained from an earlier study in which the sample was determined using EpiInfo hardware version 6.0 where the dogs were sampled in the urban and rural areas (MELO et al., 2011). The remainder samples from the others municipalities were obtained through convenience sampling, where they always sought to collect blood from all the animals in the residences.

Blood samples were collected by jugular venipuncture to obtain serum. Anti-Leishmania spp. antibodies were evaluated by immunofluorescence assay (IFA), as described by Oliveira et al. (2008), using the promastigote forms of isolate CBT 96 (Coleção Brasileira de Tripanossomatídeos) of $L$. infantum chagasi (COSTA et al., 2015) with a cut-off point at the initial dilution of 1:40 (BRASIL, 2006). Each slide contained sera previously known to be non-reactive (negative control) and reactive (positive control). Based on the finding of cross-reactivity between species of the genus Leishmania, samples that were positive in the IFA against $L$. infantum chagasi were also tested by IFA in the same conditions, using L. amazonensis and L. braziliensis antigens provided by the Oswaldo Cruz Institute (OLIVEIRA et al., 2008). 


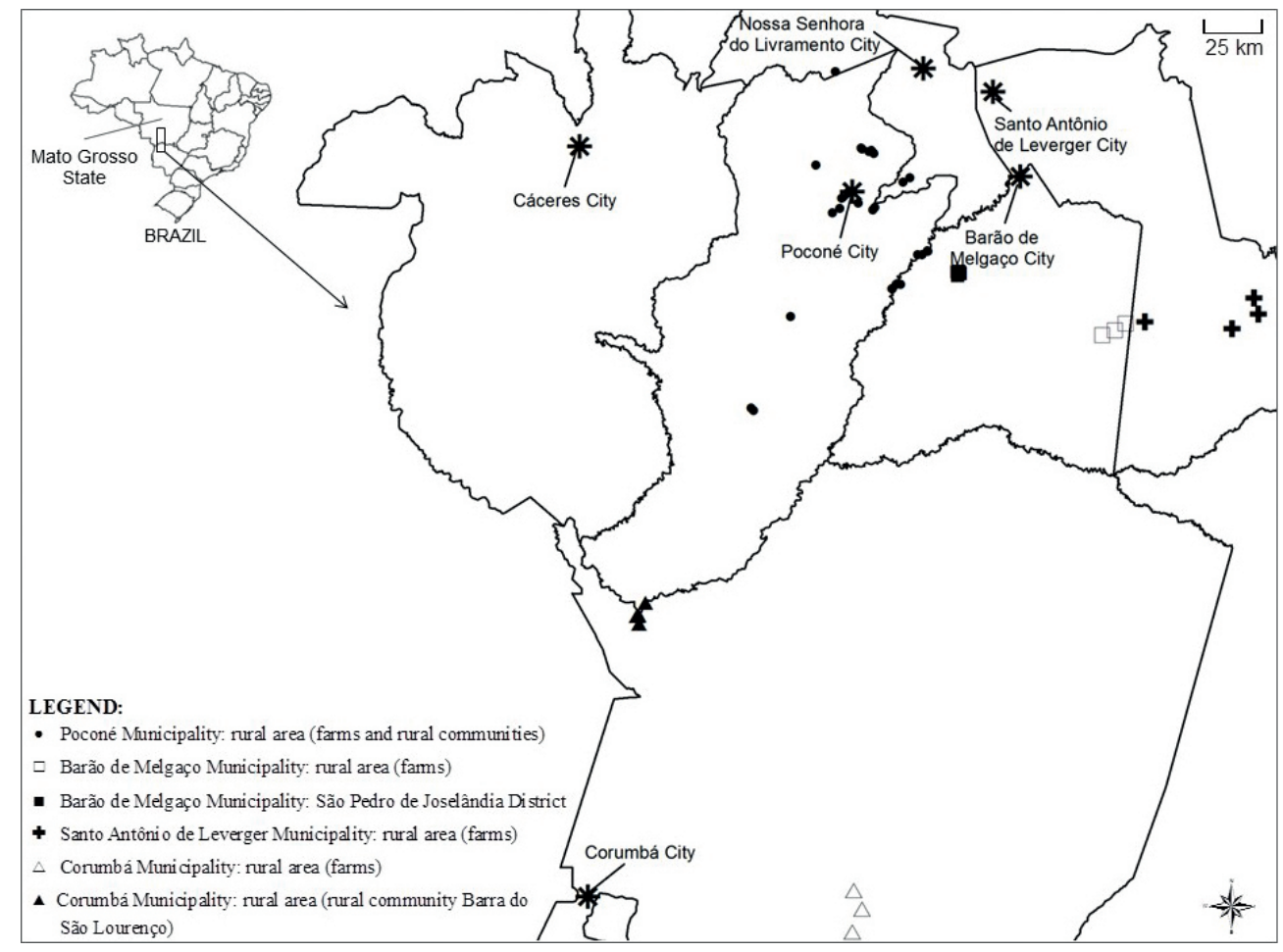

Figure 1 - Localities from the Pantanal wetland region of the States of Mato Grosso and Mato Grosso do Sul where dogs were sampled and evaluated in the presents study

IFA-positive samples were evaluated using a commercial ELISA kit based on a recombinant peptide of L. infantum chagasi, following the manufacturer's instructions (ELISA/S76, Biogene Laboratory $\left.{ }^{\circledR}\right)$. The reaction was evaluated in an ELISA reader at an optical density (OD) of 450 nanometers. The cut-off was calculated from the arithmetic mean of the optical densities of nonreactive sera added to factor $\mathrm{R}=0.142$. A gray area (indeterminate range) was established for all the plates by subtracting the cutoff of 0.03 , and serum samples with OD higher than the cut-off point were considered positive.

The owner of each dog selected for blood collection was asked to fill out a comprehensive questionnaire, which included information on the animal's age, sex, and habitat (flooded area and non-flooded area).
The present study was approved by the Bioethical Committee in Animal Research of the Federal University of Mato Grosso, under protocol no. 23108.019742/09-9.

\section{Results}

All the dogs aged 1 to 72 months and belonged to different breeds. Anti- $L$. infantum chagasi antibodies were detected in 23 (5.36\%; 95\% CI: 3.50\% - 8.05\%) dogs. At least one seroreactive dog was found in each of the municipalities evaluated in this study, and the endpoint titers ranged from 40 to 5,120. All the seropositive dogs were positive in the ELISA. According to the total number of positives, 4 (2.50\%) dogs were from the urban area of the municipality of Poconé and 19 (7.06\%) were from the rural areas of the municipalities of Poconé, Santo Antônio de Leverger, Barão de Melgaço, and Corumbá (Table 1).

Table 1 - Distribution of antibody titers against three antigens of Leishmania spp. used in IFA ( $\geq 40)$ in dogs collected in the Pantanal wetland in the states of Mato Grosso and Mato Grosso do Sul - Brazil - 2009 to 2013

\begin{tabular}{|c|c|c|c|c|c|c|}
\hline \multirow[b]{2}{*}{ Municipalities } & \multicolumn{2}{|c|}{ L. infantum chagasi } & \multicolumn{2}{|c|}{ L. amazonensis } & \multicolumn{2}{|c|}{ L. braziliensis } \\
\hline & $\begin{array}{l}\text { Positive/ } \\
\text { tested (\%) }\end{array}$ & $\begin{array}{l}\text { Endpoint titers } \\
\text { (No. of dogs) }\end{array}$ & $\begin{array}{l}\text { Positive/ } \\
\text { tested (\%) }\end{array}$ & $\begin{array}{l}\text { Endpoint titers } \\
\text { (No. of dogs) }\end{array}$ & $\begin{array}{l}\text { Positive/ } \\
\text { tested (\%) }\end{array}$ & $\begin{array}{l}\text { Endpoint titers } \\
\text { (No. of dogs) }\end{array}$ \\
\hline Poconé & $19 / 319(5.95)$ & $\begin{array}{c}40(4) ; 80(2) ; 160(5) ; 320 \\
(3) ; 640(2) ; 1280(1) 2560(2)\end{array}$ & $3 / 19$ & $40(1) ; 80(2)$ & $3 / 19$ & $80(2) ; 160(1)$ \\
\hline Santo Antônio de Leverger & $1 / 16(6.25)$ & $5120(1)$ & $1 / 1$ & $320(1)$ & $0 / 1$ & - \\
\hline Barão de Melgaço & $1 / 45(2.22)$ & $5120(1)$ & $0 / 1$ & - & $1 / 1$ & $40(1)$ \\
\hline Corumbá & 2/49 (4.08) & $40(1) ; 160(1)$ & $1 / 2$ & $80(1)$ & $0 / 2$ & - \\
\hline
\end{tabular}


Among the 23 positive dogs, nine were also positive for L. amazonensis and L. braziliensis antigens. Three dogs from Poconé were positive for L. amazonensis (titers ranging from 40 to 80), and three others were positive for L. braziliensis (titers ranging from 80 to 160). One dog from the municipality of Santo Antônio de Leverger and one dog from Corumbá were seroreactive to L. amazonensis with titers of 320 and 80 , respectively, and one dog from
Barão de Melgaço was positive for L. braziliensis (titer of 40) (Table 2).

In terms of the statistical analysis, only the variable habitat was associated with the occurrence of anti-Leishmania spp. antibodies in dogs, and a higher frequency was observed in the rural areas than in urban area $(\mathrm{P}<0.05)$. The other variables were not associated with positive serology of dogs (Table 3).

Table 2 - Endpoint titer of Leishmania infantum chagasi, L. amazonensis and L. brasiliensis found in dogs from the Pantanal wetland - Brazil - 2009 to 2013

\begin{tabular}{|c|c|c|c|c|}
\hline \multirow{2}{*}{ Municipality } & \multirow{2}{*}{ Dog } & L. infantum chagasi & L. amazonensis & L. braziliensis \\
\hline & & Titer & Titer & Titer \\
\hline \multirow[t]{6}{*}{ Poconé } & No. 1 & 160 & 80 & Negative \\
\hline & No. 2 & 2560 & 40 & Negative \\
\hline & No. 3 & 2560 & 80 & Negative \\
\hline & No. 4 & 640 & Negative & 80 \\
\hline & No. 5 & 320 & Negative & 80 \\
\hline & No. 6 & 160 & Negative & 160 \\
\hline Santo Antônio do Leverger & No. 7 & 5120 & 320 & Negative \\
\hline Barão de Melgaço & No. 8 & 5120 & Negative & 40 \\
\hline Corumbá & No. 9 & 160 & 80 & Negative \\
\hline
\end{tabular}

Table 3 - Analysis of the variables and results of IFA $(\geq 40)$ in dogs from the Pantanal wetland - Brazil - 2009 to 2013

\begin{tabular}{|c|c|c|c|}
\hline \multirow{3}{*}{ Analyzed variables } & \multicolumn{3}{|c|}{ No of dogs } \\
\hline & \multirow{2}{*}{ Analyzed } & \multicolumn{2}{|c|}{ Positive to L. infantum chagasi } \\
\hline & & Number (\%) & $P$-value \\
\hline \multicolumn{4}{|l|}{ Habitat } \\
\hline Urban & 160 & $4(2.50)$ & 0.04 \\
\hline Rural & 269 & $19(7.06)$ & \\
\hline \multicolumn{4}{|l|}{ Area } \\
\hline No flood area & 256 & $16(6.25)$ & 0.43 \\
\hline Flood area & 173 & $7(4.05)$ & \\
\hline \multicolumn{4}{|l|}{ Gender } \\
\hline Male & 258 & $11(4.26)$ & 0.30 \\
\hline Female & 171 & $12(7.02)$ & \\
\hline \multicolumn{4}{|l|}{ Age* $^{*}$} \\
\hline $0-12$ months & 124 & $3(2.42)$ & 0.13 \\
\hline 12-24 months & 100 & $8(8.0)$ & 0.27 \\
\hline 24-48 months & 94 & $9(9.57)$ & 0.07 \\
\hline 48-72 months & 50 & $1(2.0)$ & 0.49 \\
\hline$>72$ months & 48 & $2(4.17)$ & 1.00 \\
\hline
\end{tabular}

* A total of 13 dogs had not age determined; and none of these animals had antibodies to Leishmania spp.

\section{Discussion}

This study found a prevalence of anti-Leishmania spp. antibodies in dogs from the northern region of the Pantanal wetlands in three municipalities of the state of Mato Grosso and one in the state of Mato Grosso do Sul. The occurrence of canine visceral leishmaniasis has already been reported in the Pantanal region, and L. cruzi has been incriminated as a vector for this infection (SANTOS et al., 1998; BRASIL, 2016). 
Antibodies against $L$. infantum chagasi antigen were detected in $\sim 5 \%$ of dogs, with endpoint titers ranging from 40 to 5,120 , suggesting that dogs were stimulated against L. infantum chagasi. Anti-Leishmania spp. antibodies in the states of Mato Grosso and Mato Grosso do Sul have been reported by other researchers, with frequencies higher than that observed in this work and according to the particular characteristics of each region under study (NUNES et al., 2001; CORTADA et al., 2004; ANDRADE et al., 2009; ALMEIDA et al., 2012; SOUSA et al., 2013; BRITO et al., 2014). This may be related to the opportunist feeding behavior of the vector. In some areas in midwestern Brazil dogs are not the preferred sources of blood of L. longipalpis, as it was found that it feeds preferentially on birds and rodents, in addition to humans, opossums, oxen, horses, and least of all dogs (MISSAWA et al., 2008).

Positive IFA dogs were positive by ELISA using recombinant peptides of $L$. infantum chagasi and this is relevant because the ELISA is a specific test with a medium high sensitivity (GRAMICCIA, 2011), and is currently used for confirmation of seroreagent or undetermined immunochromatographic test dogs, which is recommended for screening by the Ministry of Health of Brazil (BRASIL, 2016).

On the other hand among the 23 positive dogs to IFA using $L$. infantum chagasi antigen, nine were also seroreactive to IFA performed with $L$. amazonensis and $L$. braziliensis antigens. Considering the observation of crossreactivity in IFA among different species of Leishmania spp., Trypanosoma cruzi (SOLANO-GALLEGO et al., 2009), and Trypanosoma caninum (ALVES et al., 2012), the presence of seroreagent dogs for more than one antigen suggests the possibility of a co-infection. Thus, although this test is no longer officially used by the Ministry of Health of Brazil (BRASIL, 2016), it is an important tool for the identification of $L$. infantum chagasi infection in the dogs from Pantanal region, where there are few studies about leishmaniasis

In this study most of the positive dogs clearly came from rural areas. Habitat is considered an important environmental factor in the epidemiology of leishmaniasis, mainly due to the presences of organic debris or forests close to human habitations, which can facilitate the maintenance of the vector and the occurrence of the disease (BRANDÃO-FILHO et al., 1994; MORENO et al., 2005; BIGELI et al., 2012; LOPES et al., 2014). In addition, there were more samples from rural areas than from urban areas, which may have influenced the findings of our serosurvey.

Besides degraded environments due to disordered occupation, it is known that leishmaniasis also occurs commonly in rural environments where epidemiological characteristics may facilitate the circulation of the agent (MARZOCHI et al., 2009). Furthermore, the presence of livestock and agriculture may represent a risk of disease because it can stimulate the establishment of sand flies in these environments, especially regarding that in the Pantanal area livestock activities and tourism related to fishing and safari are among the most important economic activities (MOREIRA JUNIOR et al., 2003; ALMEIDA et al., 2012). Based on these facts, the study of leishmaniasis in Brazil's Pantanal wetland is of great significance to human and animal health and it is possible to conclude that future research on this disease is essential in this region.

\section{Acknowledgments}

The authors thank J. T. de Melo and E. C. L. T. de Melo, Cuiabá, MT, Brazil, for their technical support, as well as SESC Pantanal Ecological Station, National Park of Pantanal Matogrossense, and the Chico Mendes Institute for Biodiversity Conservation - ICMBio for their logistical support. In addition, financial support for this work was provided by the following Brazilian research funding agencies: CAPES (Federal Agency for the Support and Improvement of Higher Education - Process no. 1913/2011), FAPEMAT (Research Support Foundation of the State of Mato Grosso - Process no. 263287/2010), and CNPq (National Council for Scientific and Technological Development - Process no. 472206/2011-7). We thank CAPES, FAPESP (São Paulo Research Foundation), and $\mathrm{CNPq}$ for scholarships granted to A. L. T. Melo, A. P. Costa, M. B. Stocco, T. B. S. Fernandes, T. A. Pacheco, R. Witter, T.F. Martins and A. Marcili, and for Scientific Productivity Grants awarded to R. C. Pacheco, M. B. Labruna, and D. M. Aguiar.

\section{References}

ALMEIDA, A. B. P. F.; SOUSA, V. R. F.; CRUZ, F. A. C. S.; DAHROUG, M. A. A.; FIGUEIREDO, F. B.; MADEIRA, M. F. Canine visceral leishmaniasis: seroprevalence and

risk factors in Cuiabá, Mato Grosso, Brazil. Revista Brasileira de Parasitologia Veterinária, v. 21, n. 4, p. 359-365, 2012. doi: 10.1590/S1984-29612012005000005.

Braz. J. Vet. Res. Anim. Sci., São Paulo, v. 54, n. 4, p. 375-382, 2017 
ALVES, A. S.; MOUTA-CONFORT, E.; FIGUEIREDO, F. B.; OLIVEIRA, R. V.; SCHUBACH, A. O.; MADEIRA, M. F. Evaluation of serological cross-reactivity between canine visceral leishmaniasis and natural infection by Trypanosoma caninum. Research in Veterinary Science, v. 93, n. 3, p. 13291333, 2012. doi: 10.1016/j.rvsc.2012.07.006.

ANDRADE, A. R. O.; NUNES, V. L B..; GALATI, E. A. B.; ARRUDA, C. C. P.; SANTOS, M. F. C.; ROCCA, M. E. G.; AQUINO, R. B. Epidemiological study on leishmaniasis in an area of environmental tourism and ecotourism, state of Mato Grosso do Sul, 2006-2007. Revista da Sociedade Brasileira de Medicina Tropical, v. 42, n. 5, p. 488-493, 2009. doi: 10.1590/ S0037-86822009000500003.

ASHFORD, R. W. The leishmaniases as emerging and reemerging zoonoses. International Journal for Parasitology, v. 30 , n. 12-13, p. 1269-1281, 2000. doi: 10.1016/S00207519(00)00136-3.

BAÑULS, A.; HIDE, M.; PRUGNOLLE, F. Leishmania and the leishmaniases: a parasite genetic update and advances in taxonomy, epidemiology and pathogenicity in humans. Advances in Parasitology, v. 64, p. 1-109, 2007. doi: 10.1016/ S0065-308X(06)64001-3.

BIGELI, J. G.; OLIVEIRA JUNIOR, W. P.; TELES, N. M. M. Diagnosis of Leishmania (Leishmania) chagasi infection in dogs and the relationship with environmental and sanitary aspects in the municipality of Palmas, state of Tocantins, Brazil. Revista da Sociedade Brasileira de Medicina Tropical, v. 45, n. 1, p. 18-23, 2012. doi: 10.1590/S0037-86822012000100005.

BRANDÃO-FILHO, S. P.; CARVALHO, F. G.; BRITO, M.E. F.; ALMEIDA, F. A.; NASCIMENTO, L. A. American cutaneous leishmaniasis in Pernambuco, Brazil: eco-epidemiological aspects in "Zona da Mata” region. Memórias do Instituto Oswaldo Cruz, v. 89, n. 3, p. 445-449, 1994. doi: 10.1590/ S0074-02761994000300028.

BRASIL. Ministério da Saúde. Secretaria de Vigilância em Saúde. Manual de vigilância e controle da leishmaniose visceral. Brasília, DF: Ministério da Saúde, 2006.

BRASIL. Ministério da Saúde. Secretaria de Vigilância em Saúde. Manual de vigilância, prevenção e controle de zoonoses. Brasília, DF: Ministério da Saúde, 2016.
BRITO, V. N.; OLIVEIRA, C. M.; LAZARI, P.; SOUSA, V. R. F. Epidemiological aspects of visceral leishmaniasis in Jaciara, Mato Grosso, Brazil, 2003 to 2012. Revista Brasileira de Parasitologia Veterinária, v. 23, n. 1, p. 63-68, 2014. doi: 10.1590/S1984-29612014008.

CHAPPUIS, F.; SUNDAR, S.; HAILU, A.; GHALIB, H.; RIJAL, S.; PEELING, R. W.; ALVAR, J.; BOELAERT, M. Visceral leishmaniasis: what are the needs for diagnosis, treatmentand control? Nature Reviews Microbiology, v. 5, p. 873-882, 2007. doi: 10.1038/nrmicrol748.

COSTA, A. P.; COSTA, F. B.; SOARES, H. S.; RAMIREZ, D. G.; ARAÚJO, A. C.; FERREIRA, J. I. G. S.; TONHOSOLO, R.; DIAS, R. A.; GENNARI, S. M.; MARCILI, A. Environmental factors and ecosystems associated to canine visceral leishmaniasis in Northeastern Brazil. Vector-Borne and Zoonotic Diseases, v. 15, n. 12, p. 765-774, 2015. doi: 10.1089/vbz.2015.1866.

CORTADA, V. M. C. L.; DOVAL, M. E. C.; SOUZA, M. A. A. L.; OSHIRO, E. T.; MENESES, C. R. V.; ABREU-SILVA, A. L.; CUPOLILO, E.; SOUZA, C. S. F.; CARDOSO, F. O.; ZAVERUCHA, T. V.; BRAZIL, R. P.; CALABRESE, K. S.; COSTA, S. C. G. Canine visceral leishmaniosis in Anastácio, Mato Grosso do Sul state, Brazil. Veterinary Research Communications, v. 28, n. 5, p. 365-374, 2004. doi: 10.1023/B:VERC.0000035014.80785. b7.

DAWIT, G.; GIRMA, Z.; SIMENEW, K. A review on biology, epidemiology and public health significance of leishmaniasis. Journal of Bacteriology and Parasitology, v. 4, n. 2, p. 1000166, 2013. doi: 10.4172/2155-9597.1000166.

DIAS, F. O. P.; LOROSA, E. S.; REBÊLO, J. M. M. Fonte alimentar sanguínea e a peridomiciliação de Lutzomyia longipalpis (Lutz \& Neiva, 1912) (Psychodidae, Phlebotominae). Cadernos de Saúde Pública, v. 19, n. 5, p. 1373-1380, 2003. doi: 10.1590/S0102311X2003000500015.

GRAMICCIA, M. Recent advances in leishmaniosis in pet animals: epidemiology, diagnostics and anti-vectorial prophylaxis. Veterinary Parasitology, v. 181, n. 1, p. 23-30, 2011. doi: 10.1016/j.vetpar.2011.04.019. 
HEUSSER JÚNIOR, A.; BELLATO, V.; SOUZA, A. P.; MOURA, A. B.; SARTOR, A. A.; SANTOS, E. G. O. B.; SILVA, V. L. Leishmaniose tegumentar canina no município de Balneário Camboriú, estado de Santa Catarina. Revista da Sociedade Brasileira de Medicina Tropical, v. 43, n. 6, p. 713-718, 2010. doi: 10.1590/S003786822010000600023.

LAINSON, R.; RANGEL, E. F. Lutzomyia longipalpis and the eco-epidemiology of American visceral leishmaniasis, with particular reference to Brazil: a review. Memórias do Instituto Oswaldo Cruz, v. 100 , n. 8 , p. $811-827,2005$. doi: 10.1590/S007402762005000800001.

LOPES, P. M.; BOA SORTE, E. C.; GASPARETTO, N. D.; OLIVEIRA, C. M.; ALMEIDA, A. B. P. F.; SOUSA, V. R. F. Seroprevalence and risk factors associated with visceral leishmaniasis in dogs in Jaciara, state of Mato Grosso. Revista da Sociedade Brasileira de Medicina Tropical, v. 47, n. 6, p. 791-795, 2014. doi: 10.1590/00378682-0027-2014.

MARZOCHI, M. C. A.; FAGUNDES, A.; ANDRADE, M. V.; SOUZA, M. B.; MADEIRA, M. F.; MOUTACONFORT, E.; SCHUBACH, A. O.; MARZOCHI, K. B. F. Visceral leishmaniasis in Rio de Janeiro, Brazil: eco-epidemiological aspects and control. Revista da Sociedade Brasileira de Medicina Tropical, v. 42 , n. 5, p. 570-580, 2009. doi: 10.1590/S003786822009000500017 .

MELO, A. L. T.; MARTINS, T. F.; HORTA, M. C.; MORAES-FILHO, J.; PACHECO, R. C.; LABRUNA, M. B.; AGUIAR, D. M. Seroprevalence and risk factors to Ehrlichia spp. and Rickettsia spp. in dogs from the Pantanal region of Mato Grosso state, Brazil. Ticks and Tick-Borne Diseases, v. 2, n. 4, p. 213-218, 2011. doi: 10.1016/j.ttbdis.2011.09.007.

MOREIRA JUNIOR, E. D.; SOUZA, V. M. M.; SREENIVASAN, M.; LOPES, N. L.; BARRETO, R. B.; CARVALHO, L. P. Peridomestic risk factors for canine leishmaniasis in urban dwellings: new findings from a prospective study in Brazil. The American Journal of Tropical Medicine and Hygiene, v. 69, n. 4, p. 393-397, 2003. doi: 10.4269/ajtmh.2003.69.393.
MISSAWA, N. A.; LIMA, G. B. M. Distribuição espacial de Lutzomyia longipalpis (Lutz \& Neiva, 1912) e Lutzomyia cruzi (Mangabeira, 1938) no estado de Mato Grosso. Revista da Sociedade Brasileira de Medicina Tropical, v. 39, n. 4, p. 337340, 2006. doi: 10.1590/S0037-86822006000400004.

MISSAWA, N. A.; LOROSA, E. S.; DIAS, E. S. Preferência alimentar de Lutzomyia longipalpis (Lutz \& Neiva, 1912) em área de transmissão de leishmaniose visceral em Mato Grosso. Revista da Sociedade Brasileira de Medicina Tropical, v. 41, n. 4, p. 365-368, 2008. doi: 10.1590/S003786822008000400008 .

MORENO, E. C.; MELO, M. N.; GENARO, O.; LAMBERTUCCI, J. R.; SERUFO, J. C.; ANDRADE, A. S. R.; ANTUNES, C. M. F.; CARNEIRO, M. Risk factors for Leishmania chagasi infection in an urban area of Minas Gerais state. Revista da Sociedade Brasileira de Medicina Tropical, v. 38, n. 6, p. 456-463, 2005. doi: 10.1590/S003786822005000600002.

NUNES, V.L. B.; GALATI, E. A. B.; NUNES, D. B.; ZINEZZI, R. O.; SAVANI, E. S. M. M.; ISHIKAWA, E.; CAMARGO, M. C. G. O.; D’ÁURIA, S. R. N.; CRISTALDO, G.; ROCHA, H. C. Ocorrência de leishmaniose visceral canina em assentamento agrícola no Estado de Mato Grosso do Sul, Brasil. Revista da Sociedade Brasileira de Medicina Tropical, v. 34, n. 3, p. 301302, 2001. doi: 10.1590/S0037-86822001000300014.

OLIVEIRA, T. M. F. S.; FURUTA, P. I.; CARVALHO, D.; MACHADO, R. Z. Study of cross-reactivity in serum samples from dogs positive for Leishmania sp., Babesia canis and Ehrlichia canis in enzyme-linked immunosorbent assay and indirect fluorescent antibody test. Revista Brasileira de Parasitologia Veterinária, v. 17, n. 1, p. 7-11, 2008. doi: 10.1590/S1984-29612008000100002.

ROQUE, A. L. R.; JANSEN, A. M. Wild and synanthropic reservoirs of Leishmania species in the Americas. International Journal for Parasitology: Parasites and Wildlife, v. 3, n. 3, p. 251-262, 2014. doi: 10.1016/j.ijppaw.2014.08.004.

SANTOS, S. O.; ARIAS, J.; RIBEIRO, A. A.; HOFFMANN, M. P.; FREITAS, R. A.; MALACCO, M. A. F. Incrimination of Lutzomyia cruzi as a vector of American visceral leishmaniasis. Medical and Veterinary Entomology, v. 12, n. 3, p. 315-317, 1998. doi: 10.1046/j.1365-2915.1998.00104.x. 
SARAIVA, L.; LEITE, C. G.; LIMA, A. C. V. M. R.; CARVALHO, L. O. A.; PEREIRA, A. A. S.; RUGANI, J. M. N.; REGO, F. D.; GONTIJO, C. M. F.; ANDRADE FILHO, J. D. Seasonality of sand flies (Diptera: Psychodidae) and Leishmania DNA detection in vector species in an area with endemic visceral leishmaniasis. Memórias do Instituto Oswaldo Cruz, v. 112, n. 4, p. 309-318, 2017. doi: 10.1590/0074-02760160438.

SOUSA, K. C. M.; ANDRÉ, M. R.; HERRERA, H. M.; ANDRADE, G. B.; JUSI, M. M. G.; SANTOS, L. L.; BARRETO, W. T. G.; MACHADO, R. Z.; OLIVEIRA,
G. P. Molecular and serological detection of tick-borne pathogens in dogs from an area endemic for Leishmania infantum in Mato Grosso do Sul, Brazil. Revista Brasileira de Parasitologia Veterinária, v. 22, n. 4, p. 525-531, 2013. doi: 10.1590/S1984-29612013000400012.

SOLANO-GALLEGO, L.; KOUTINAS, A.; MIRÓ, G.; CARDOSO, L.; PENNISI, M. G.; FERRER, L.; BOURDEAU, P.; OLIVA, G.; BANETH, G. Directions for the diagnosis, clinical staging, treatment and prevention of canine leishmaniosis. Veterinary Parasitology, v. 165, n. 1-2, p. 1-18, 2009. doi: 10.1016/j.vetpar.2009.05.022. 